\title{
Ergonomic Conditions in Small Manufacturing Industries
}

\author{
Ashraf A. Shikdar and Saeed A. Al-Araimi
}

Department of Mechanical and Industrial Engineering, College of Engineering, Sultan Qaboos University, P.O. Box 33, Al Khod 123, Muscat, Sultanate of Oman.

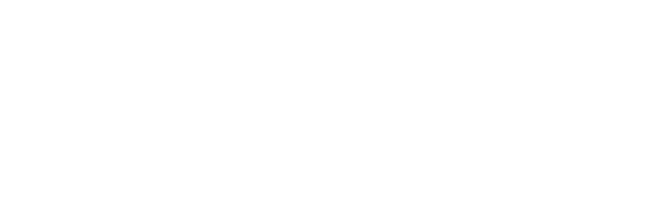

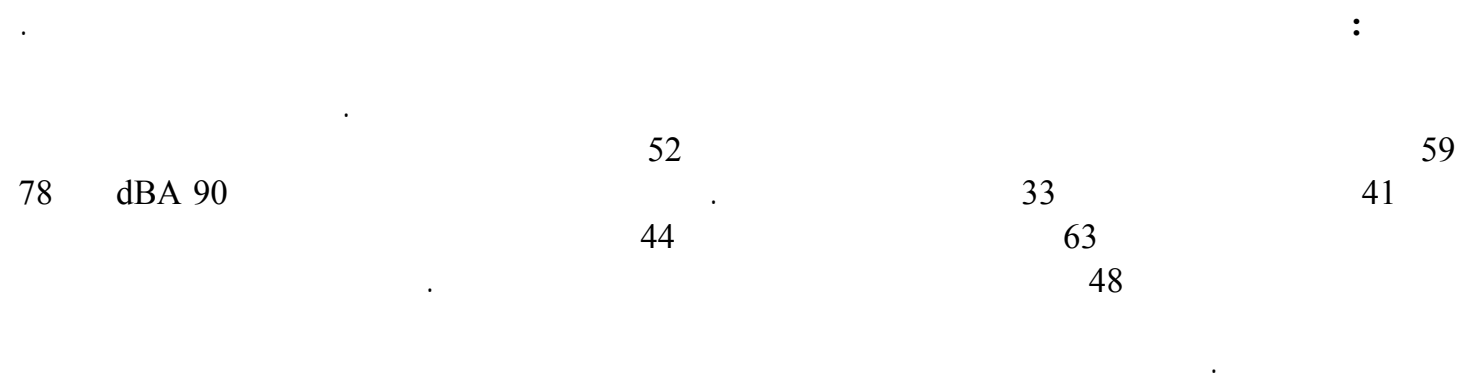

ABSTRACT: Ergonomic conditions in small manufacturing industries were investigated. Twenty seven managers of small manufacturing industries participated in the study. Old equipment and machines, poorly designed workplaces, lack of systematic planning, layout and organization, unsafe working conditions and poor environment were found common to these industries. Fifty-nine percent of companies indicated having equipment older than 15 years. Fifty-two percent of company managers reported receiving complaints of fatigue from their workforce, $41 \%$ complaints of back pain, and 33\% complaints of upper-body pain. Seventy eight percent of companies reported a noisy environment (above $90 \mathrm{dBA}$ ) while $63 \%$ reported a hot environment. Management in $44 \%$ of the companies acknowledged failure to ensure safety rules and $48 \%$ did not provide training on manual material handling. Lack of skills in ergonomics and training, communication and resources are believed to be some of the factors contributing to the poor ergonomic conditions in a sample of small manufacturing industries in Malaysia.

KEYWORDS: Ergonomics, Small Manufacturing Industry, Worker Productivity and Occupational Health and Safety.

\section{Introduction}

$\mathbf{E}$ rgonomics or Human Factors Engineering deals with the application of information about human behavior, capabilities and limitations to the design of systems, machines, tools, tasks, and environment for productive, safe and effective human use. A manufacturing industry is a complex human-machine-environment-organization system. For productive and effective functioning of this system management should ensure optimum functioning of the system components.

There is a growing concern of improving productivity, safety, and quality in manufacturing industries. Some of the common features of these industries are improper workplace design, illstructured jobs, mismatch between worker abilities and job demands, adverse environment, poor 
human-machine system design and inappropriate management programs. They lead to workplace hazards, poor workers health, mechanical equipment injuries, disabilities, and in turn reduce worker productivity and product/work quality and increase cost. It would, therefore, be extremely difficult to attain the above objectives of the manufacturing industries without giving proper consideration to ergonomics.

Effective application of ergonomics in work system design can achieve a balance between worker characteristics and task demands. This can enhance worker productivity, provide worker safety and physical and mental well-being and job satisfaction. Many research studies have shown positive effects of applying ergonomic principles in workplaces, machine design, job design, environment and facilities design (Hasselquist, 1981; Rayan, 1989; Schnauber, 1986; Burry and Helander, 1991; Das, 1987; Shikdar and Das, 1995; Das and Sengupta, 1996; Resnik and Zenotti, 1997; Das and Shikdar, 1999).

Studies in ergonomics have also produced data and guidelines for industrial applications. The features of ergonomic design of machines, workstations, facilities are well known (Grandjean, 1982; Konz, 1983; Sanders and McCormic, 1992; Das and Grady, 1983; Rayan, 1987; Melamed et al, 1989). However, there is still a low level of acceptance and limited application in manufacturing industries, especially in small manufacturing industries. The main concern of work system design is usually the improvement of machines and tools alone. Inadequate or no consideration is given to the work system as a whole. Therefore, poorly designed work systems are a common place in manufacturing industries (Konz, 1983; Das, 1987). Neglect of ergonomic principles brings inefficiency and pain to the workforce. An ergonomically deficient workplace can cause physical and emotional stress, low productivity and poor quality of work (Ayoub, 1990a, 1990b).

Small manufacturing industries are considered as manufacturing establishments employing 20 people or less in some places, where as in other places they are considered having less than 50 or even 100 workers. Majority of the manufacturing industries are small and large facilities employing hundreds or thousand of workers are only a small fraction of the total manufacturing industries (Zaidel, 1989). Small manufacturing industries have specific characteristics differing from large industries in terms of facilities, resources and work systems. Some of the characteristics of small manufacturing industries are: the manager is usually the owner, do not have occupational health and safety (OHS) committee, ergonomics specialists or trained personnel, usually they are located in small premises unsuitable for industrial facility, and in extremely poor conditions (Zaidel, 1989). However, this study concentrated on characterizing small manufacturing shops and did not focus on ergonomic conditions of these shops.

Large manufacturing industries on the other hand have better awareness about ergonomics, OHS committees, personnel and resources to tackle ergonomics, productivity and safety issues. Professional literature with regard to the introduction of ergonomics and safety improvements deals almost exclusively with medium and large industries. No specific study could be found in the literature on ergonomic conditions of small manufacturing industries.

It is believed ergonomic deficiencies in manufacturing industries are the root causes of workplace health hazards, low level of safety and reduced worker productivity and quality. The ergonomic conditions in small manufacturing industries could be even more severe as these industries face compounding problems due to their characteristics. While Ergonomics applications have gained momentum in large manufacturing industries, it is lacking severely in small manufacturing industries. Therefore, the objective of this research was to conduct a study to assess the ergonomic conditions of small manufacturing industries.

\section{Methodology}

The methodology for investigating ergonomic conditions in small manufacturing industries involved: (1) development of a checklist that was mailed to the managers of industries, and (2) physically assess selected industries for ergonomic deficiencies. In this study small manufacturing industries were considered industries employing up to 50 people. A list of 100 small manufacturing 


\section{ERGONOMIC CONDITIONS IN SMALL MANUFACTURING INDUSTRIES}

industries was created from the directory of industry based on this criterion in the category of metal and metal products manufacturing. The list was representative of small manufacturing industries in the country.

Ergonomic problems/deficiencies may exist in any of the following system components of any manufacturing industry: 1. Human Operator, 2. Equipment, 3. Task, 4. Workplace, 5. Environment, 6. Management.

Table 1 shows some major ergonomic attributes in each of these system components. The checklist was developed to collect information about these ergonomic attributes in small manufacturing industries. The checklist contained questions that required the managers to provide information as well as ticking the appropriate answers. For example, the manager of the company was required to tick the Yes/No box for the question 'Do you provide a formal safety training to your workers?'.

Table 1: Major ergonomic attributes in system components.

\begin{tabular}{|l|l|}
\hline $\begin{array}{l}\text { System } \\
\text { Components }\end{array}$ & Ergonomic Attributes \\
\hline Human Operator & $\begin{array}{l}\text { Job training, safety training, skills, knowledge, } \\
\text { posture, personal protective equipment, stress, } \\
\text { fatigue, job satisfaction }\end{array}$ \\
\hline Equipment & $\begin{array}{l}\text { Design, emergency safety features, guards, } \\
\text { access, controls and displays, installation, } \\
\text { condition, maintenance }\end{array}$ \\
\hline Task & $\begin{array}{l}\text { Design, method, safety, jigs and fixtures, manual } \\
\text { material handling, skills required, fatigue and rest } \\
\text { period, repetition }\end{array}$ \\
\hline Workplace & $\begin{array}{l}\text { Physical space, layout of components, work } \\
\text { height, seating arrangement, work chair design, } \\
\text { material movement }\end{array}$ \\
\hline Environment & $\begin{array}{l}\text { Noise, heat, humidity, light, ventilation, dust, } \\
\text { pollution, vibration, shopfloor condition, } \\
\text { housekeeping }\end{array}$ \\
\hline Management & $\begin{array}{l}\text { Plant layout, hazard recognition, ergonomics and } \\
\text { safety programs, OHS compliance, standard } \\
\text { setting, feedback, attitude }\end{array}$ \\
\hline
\end{tabular}

The checklist was mailed to the selected small manufacturing industries in Perak and Selangor states of Malaysia and the managers of the companies were requested to return the completed questionnaire in the potage paid envelopes in confidence. They were also asked if the researcher could visit the company to physically inspect the workplace to verify the information provided in the questionnaire. Twenty-seven companies returned the completed questionnaires and seven of these companies participated for a physical inspection of their companies. All the companies were in the same category (metal and metal products manufacturing) and employed between 7 and 50 people with an average of 23 people. The companies were located in the same geographical area. The physical inspection was intended to verify some of the answers in the checklist, such as confirming noise level, temperature, housekeeping, machine conditions, etc.

\section{Results}

The data obtained from the industries $(\mathrm{n}=27)$ were analyzed in terms of frequency of positive or negative response to each question. Table 2 presents some major responses in terms of frequency and percentage from the mangers. The analysis of the data showed serious ergonomic 
deficiencies in all the system components of small manufacturing industries. There was no ergonomic soundness in work systems in most of the cases. Seldom the works were conducted in good ergonomic conditions. Detailed analysis of the results is presented below.

Table 2: Manager's response to some major ergonomic attributes $(n=27)$, (PPE: personal safety equipment; OHS : occupational health and safety; MMH: Manual Material Handing).

\begin{tabular}{|c|c|c|c|}
\hline $\begin{array}{l}\text { System } \\
\text { Components }\end{array}$ & Ergonomic Attributes & $\begin{array}{l}\text { Positive } \\
\text { Response }\end{array}$ & $\begin{array}{c}\text { Percentage } \\
(\%)\end{array}$ \\
\hline $\begin{array}{l}\text { Human } \\
\text { Operator }\end{array}$ & $\begin{array}{l}\text { - Worker complaints } \\
\text { i. Fatigue } \\
\text { ii. Headache } \\
\text { iii. Backache/pain } \\
\text { iv. Shoulder/neck pain } \\
\text { v. Hand/arm soreness } \\
\text { - Worker Training } \\
\text { i. Safety } \\
\text { ii. Ergonomics } \\
\text { iii. MMH } \\
\text { - Worker Training } \\
\text { i. Use PPE }\end{array}$ & $\begin{array}{c}14 \\
11 \\
11 \\
9 \\
8 \\
0 \\
0 \\
14 \\
18\end{array}$ & $\begin{array}{c}52 \\
41 \\
41 \\
33 \\
30 \\
\\
0 \\
0 \\
52 \\
\\
67\end{array}$ \\
\hline Equipment & $\begin{array}{l}\text { - Equipment condition } \\
\text { i. Very old }(>15 \text { yrs }) \\
\text { ii. Adequate guarding } \\
\text { iii. Modifications made }\end{array}$ & $\begin{array}{l}16 \\
22 \\
11\end{array}$ & $\begin{array}{l}59 \\
81 \\
41\end{array}$ \\
\hline Task & $\begin{array}{l}\text { - Task design } \\
\text { i. Methods and time study } \\
\text { ii. Jig/fixture, work aid } \\
\text { iii. Specific work method }\end{array}$ & $\begin{array}{c}0 \\
18 \\
21 \\
\end{array}$ & $\begin{array}{l}0 \\
67 \\
87 \\
\end{array}$ \\
\hline Workplace & $\begin{array}{l}\text { - Workplace design } \\
\text { i. Use anthropometric data } \\
\text { ii. Postural flexibility } \\
\text { iii. Systematic layout } \\
\text { iv. Seating }\end{array}$ & $\begin{array}{c}0 \\
11 \\
3 \\
16\end{array}$ & $\begin{array}{c}0 \\
41 \\
11 \\
59\end{array}$ \\
\hline Environment & $\begin{array}{l}\text { - Environment condition } \\
\text { i. Noisy ( }>90 \mathrm{dBA}) \\
\text { ii. Hot and Humid } \\
\text { iii. Dusty }\end{array}$ & $\begin{array}{l}21 \\
17 \\
10\end{array}$ & $\begin{array}{l}78 \\
63 \\
37\end{array}$ \\
\hline Management & $\begin{array}{l}\text { - Management programs } \\
\text { i. Ensure safety rules } \\
\text { ii. Ergonomics program } \\
\text { iii. Motivating workers } \\
\text { iv. Housekeeping } \\
\text { v. Compliance with OHS }\end{array}$ & $\begin{array}{c}12 \\
0 \\
5 \\
22 \\
33\end{array}$ & $\begin{array}{c}44 \\
0 \\
19 \\
81 \\
85\end{array}$ \\
\hline
\end{tabular}

\subsection{Human Operator}

The human operator is the most vital link in the Human-Machine-Environment system. The system performance is largely dependent on the human operator. However, the operator is given little or no consideration in the work system design, especially in small manufacturing industries. The survey indicated ergonomics is seldom used and practically no ergonomics or safety training is provided to operators. Operators complained of fatigue in $52 \%$, back pain in $41 \%$, shoulder or neck 
pain in 33\% and hand or arm soreness in 30\% of the companies surveyed. In an earlier study (Shikdar et al, 1993) it was found that operators were unable to work in a normal standing or sitting postures due to poorly designed and installed machines, poorly designed work, inappropriate work heights and lack of suitable work chairs. Poor work practices, especially in manual material handling, failing to wear personal safety equipment (PPE), lack of training for safe use of equipment, were very common. Operators used inappropriate apparels. Figure 1 shows some major worker complaints with respect to health and safety in small manufacturing industries.

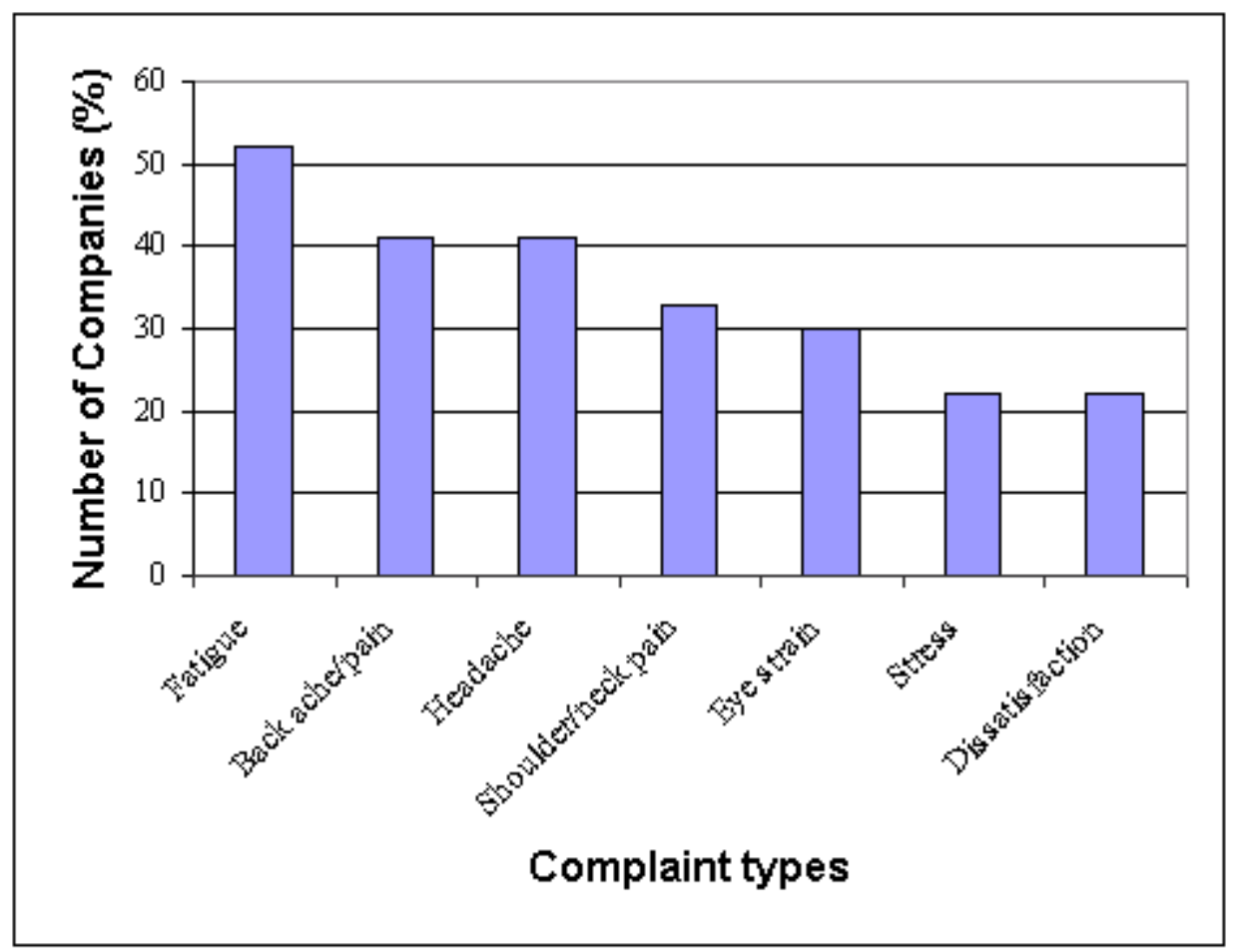

Figure 1. Some major worker complaints.

Operators were observed to work for considerably long periods of time. An understanding of human error is essential in such working conditions. The operators did not have any knowledge of ergonomics or its application for safe use of machinery and work practices. The physical inspection of the seven industries in the study showed similar results; such as operators were found not wearing PPE in the shopfloor. Lack of experience and training $(52 \%)$, fatigue $(30 \%)$ and carelessness $(26 \%)$ were sighted as the major causes of accidents and injuries.

\subsection{Equipment}

It is a fundamental principle of ergonomics that machines must be safe in operation and maintenance. However, it often becomes a source of injury in manufacturing industry. Ergonomically designed equipment and proper safety training can significantly reduce accidents and injuries from equipment. Little or no safety training is provided to workers in small manufacturing industries. The equipment is never assessed in terms of ergonomics. About $59 \%$ of the companies indicated they have machines that are older than 15 years and $41 \%$ companies required some sort of modifications in the machines. The modifications were mainly intended to improve machine performance and quality and seldom it was meant to improve safety of the workers. However, mechanical equipment has been blamed as the major source of injuries (59\%). Most of old equipment lacks in ergonomic design. In an earlier study, 370 machines were assessed and $91 \%$ were found poorly designed in terms of ergonomics (Shikdar et al, 1993). Among the 
ergonomic attributes of machine design, which were considered safety problems were traps, moving parts, controls and guards.

These are, obviously, potential hazards and the sources of injuries in small factories. Physical inspection showed unprotected cutting or working areas were common and there was easy access to these areas. Moreover, controls were poorly designed which could cause accidents. There was a clear lack of necessary machine accessories including jigs and fixtures. Safety features such as machine guards and emergency stops, etc. were either non-existent or were not in use. Those machinery which had emergency stops were poorly located. Companies with high mechanical injuries tended to have poorly designed machines and machines in poor condition due to poor maintenance (Gardner et al, 1997). The installation of machines allowed easy access to dangerous areas too. Non-ergonomically designed hand tools were very common with these industries. Application of ergonomics to the design and safe use of machinery is virtually non-existent in small manufacturing industries (Shikdar et al, 1993).

\subsection{Task}

Small manufacturing industries depend mostly on contract jobs from the large industries. Tasks are poorly designed with some specific work procedure or some instructions are provided to the workers for task performance. Companies reported following a specific method (78\%) although none of the companies reported using methods and time study. Adequate postural control, appropriate visual requirements, need for repetitive movements, and manual material handling are not given adequate considerations. Companies with better work design reportedly had fewer accidents (Shikdar, et al, 1993). Operators were found not using personal safety equipment (33\%) in the tasks requiring the equipment. Little or no consideration was given to matching the tasks to the operators in small industries. About $48 \%$ companies did not provide any training in manual material handling. Manual material handling is a major source of occupational health hazards.

\subsection{Workplace}

Physical inspection showed most of the small manufacturing industries were housed in unsuitable premises. Workplaces were poorly designed. Ergonomic guidelines have seldom been followed and no data such as anthropometric data for ergonomic design of the workplaces were available. There was inadequate working space, and workplaces were assessed as having poor workplace layout and not organized although $41 \%$ companies showed having considered postural flexibility. Obstructions and crowding of equipment and materials were common in the seven companies studied in the physical inspection. Although 59\% companies reported that they provide

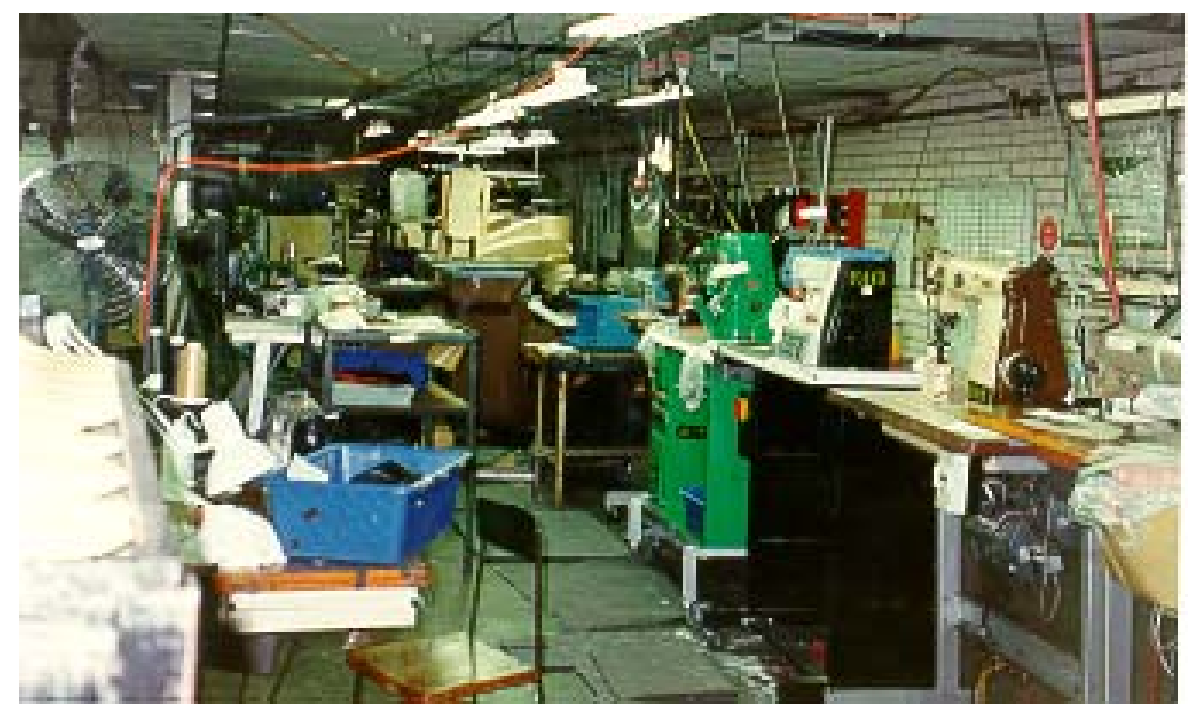

Figure 2. A typical small manufacturing industry. 
seating arrangements for the workers, the inspection indicated the chairs and other seating arrangements were poorly designed. In the layout and design of workspaces the owners did not follow any systematic procedure. Similar results were obtained in the earlier study (Shikdar et al, 1993). Figure 2 shows a typical small manufacturing industry with no ergonomic consideration. Working posture is largely affected by workplace design. Therefore, appropriate application of ergonomic data in the design of the workplace can significantly reduce musculoskeletal injuries in the workplace.

\subsection{Environment}

Figure 3 shows some major environmental problems in the shopfloor of small manufacturing industries. The main problems reported in terms of environment, in the surveys were excessive noise $(78 \%)$, hot $(63 \%)$ and dusty environments. Excessive noise was considered a sound level above $90 \mathrm{dBA}$ most of the time during the work shift. This was probably because the factories were operated in unsuitable premises. High noise level tended to be the feature of old equipment resulting in the need for protective measures. Hot environment was considered to be an air temperature of $30{ }^{\circ} \mathrm{C}$ and above. It was reported that in $33 \%$ cases the operators were not using earmuffs or earplugs although there was no shortage of personal safety equipment. There was no provision to control temperature in the shopfloor, however operators wore clothing according to their needs. Physical measurement in the seven audited companies confirmed these environmental conditions.

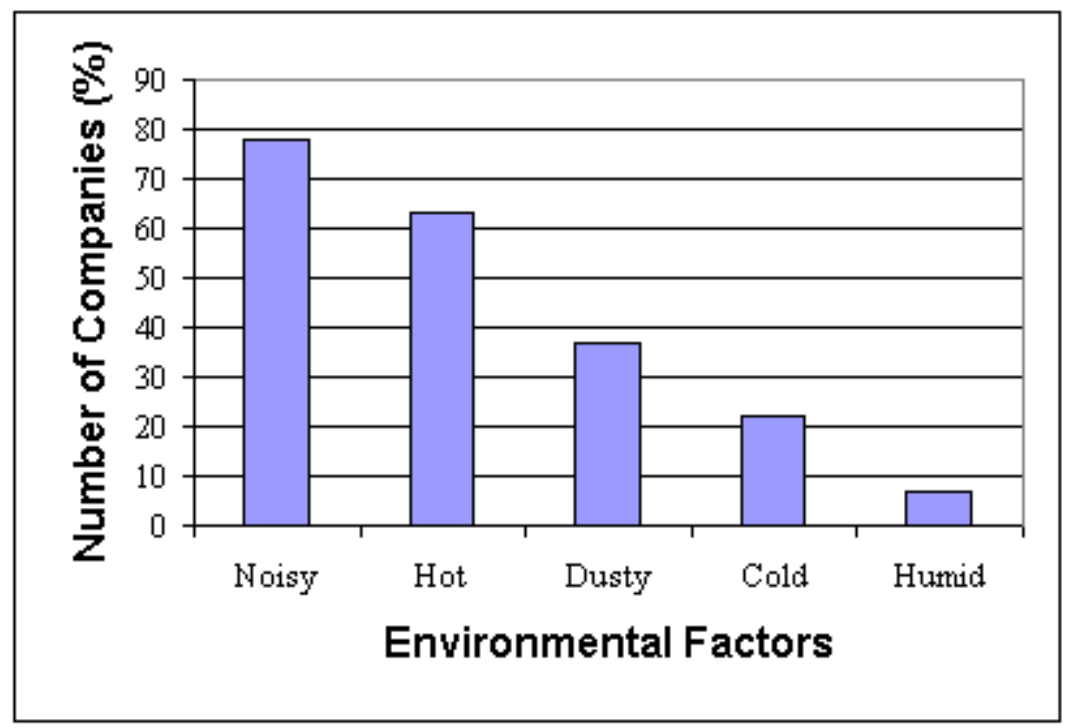

Figure 3. Some major environmental problems in industries

Performance of machine tasks under adverse conditions could lead to accidents and injuries. Therefore, adequate consideration should be given to environment design in small factories. Similar results were observed in an earlier study (Shikdar, et al, 1993).

\subsection{Management}

As stated earlier, most of the small factories were not systematically organized. Constraint on space probably prohibited systematic plant layout. Poor housekeeping was a common feature of the industries inspected, although, in about $81 \%$ cases the factories reported that they carry out housekeeping on a regular basis or when required. The inspection showed most companies did not have proper storage areas and materials were left laying around (Figure 2). Obstructions in the aisles and work areas were quite common. No ergonomics or safety programs were enforced. Management of some of these industries acknowledged of failing to ensure safety rules (44\%); 
such as wearing PPE. As reported earlier the manager is usually the owner in most small factories, so in many cases they work with other operators on the shopfloor. Therefore, the communication is usually verbal and casual (Zaidel, 1989; Shikdar et al, 1993).

\section{Discussions}

The principles of ergonomics are directly relevant to the design of workplaces, machines, machine guards, displays and controls and hand tools. Ergonomic design of equipment applies fundamental principles and techniques of safeguarding and providing safety devices for the protection of operators. There should also be adequate warning and instructions for safe operation and maintenance of machines. Despite wide spread use of guards, devices, and personal protective equipment, injuries and even deaths occur with increasing frequency. This indicates a lack of appropriate application of ergonomics in design, operation and interface. Inadequate or no formal safety training, poor knowledge of hazard recognition and prevention could further aggravate the problem. A large number of unsafe and poorly designed machines and workplaces are in use in small manufacturing industries. Designing out problems that can cause accidents and injuries is a better solution to preventing accidents and injuries. Designing out ergonomic deficiencies can significantly reduce injuries.

Although the managers' response do not indicate a high accident and injury rate, the ergonomic deficiencies are clearly significant. Some ergonomics are applied indirectly since the companies have to ensure occupational health and safety (OHS) regulations imposed by the government. The OHS problems identified in the study are related to ergonomic deficiencies in the system components. By designing out ergonomic deficiencies, not only accidents and injuries would reduce, but also improve worker productivity and satisfaction.

Small manufacturing industries have a high mechanical equipment injury rate (Shikdar et al, 1993; Gardner et al, 1997). The ergonomic problems identified in the study were probably responsible for the high incidence rate. Physical safety problems were severe. Lack of ergonomics knowledge and awareness of the employers and employees could be responsible for the poor acceptance of ergonomics in the workplace. Management did not check the workplaces for unsafe features and did not enforce safety rules, or provide instructions and training for safe performance. Even hazard signs were not displayed in unsafe places.

The poor ergonomic conditions in small manufacturing industries not only hinder productivity but also affect health and safety of workers and quality of works and products. The study is unique as professional literature with regard to the introduction of ergonomics and safety improvements deals almost exclusively with medium and large industries. No study could be found that deals specifically with ergonomic conditions and their improvements in small manufacturing industries. Since most manufacturing industries are small, attention must be given to improving ergonomic conditions of these industries.

\section{Conclusions}

The study indicates that the following conclusions could be drawn regarding ergonomic conditions in small manufacturing industries in Malaysia:

1. Ergonomics is seldom used in small manufacturing industries. Most of the industries studied have used little or no ergonomics information and data. Eighty-one percent of the companies did not carry out ergonomic assessment of their companies.

2. Non-ergonomically designed equipment and workplaces are common in small manufacturing industries as evident from the physical audit. Fifty-nine percent of the companies have old $(>15$ years) equipment. The old equipment is a potential hazard for accidents and injuries as they are less likely to have been ergonomically designed. Mechanical equipment is blamed by $59 \%$ of the managers as the major cause of injuries. 


\section{ERGONOMIC CONDITIONS IN SMALL MANUFACTURING INDUSTRIES}

3. Worker complaints of fatigue, back pain, headache, and upper body pain were reported in 52\%, $41 \%, 41 \%$, and $33 \%$ of the companies, respectively. These health problems are serious indications of ergonomic deficiencies in the work system of small manufacturing industries.

4. Poor environmental condition, especially noisy and hot, is common to most of the small industries and little consideration is given to improving it. Seventy-eight percent of the companies had excessive noise ( $>90 \mathrm{dBA})$ and $63 \%$ of the companies reported hot environment. Adverse environmental condition in the shopfloor could aggravate accidents and injuries further.

5. Most of the small manufacturing industries either did not have knowledge of ergonomics, access to ergonomics information or they simply ignored it considering resource constraints and costs.

As the majority of industries are small and since it is a source of employment and support for the economy, drastic and systematic measures and changes are required in the set up and operation of small manufacturing industries. Some of the strategies as evident from the study are stated below.

a. Employees and management must be knowledgeable and aware of benefits of ergonomics and the prevention of injuries through ergonomic design of work system. Information on ergonomics should be available to small manufacturing industries.

b. The old and unsafe equipment should systematically be replaced or upgraded in order to have better ergonomically designed equipment to reduce accidents and injuries. Ergonomic evaluation should be carried out on equipment before purchasing them.

c. The work and workplace design should be carried out using ergonomic guidelines, acts and recommendations considering user population. Environment must be given adequate consideration.

d. Strategies should be formulated and implemented in order to introduce ergonomics systematically in small manufacturing industries to improve worker productivity, safety, health and environment.

\section{Acknowledgement}

The authors acknowledge the contribution of Mr. Rajendran in the data collection process.

\section{References}

AYOUB, M.A. 1990a. Ergonomic deficiencies: I. Pain at work. Journal of Occupational Medicine, 32: $52-57$.

AYOUB, M.A. 1990b. Ergonomic deficiencies: II. Probable causes. Journal of Occupational Medicine, 32: 131-136.

BURRI, G.J. and HELANDER, M.G. 1991. A field study of productivity improvements in the manufacturing of circuit boards. International Journal of Industrial Ergonomics, 7: 207-215.

DAS, B. 1987. An ergonomic approach to designing a manufacturing work system. International Journal of Industrial Ergonomics, 1: 231-240.

DAS, B. and GRADY, R.M. 1983. Industrial workplace layout design: An application of engineering anthropometry. Ergonomics, 26: 433-443.

DAS, B. and SENGUPTA, A. 1996. Industrial workstation design: A systematic ergonomic approach. Applied Ergonomics, 27: 157-163.

DAS, B. and SHIKDAR, A. 1999. Participative versus assigned production standard setting in a repetitive industrial task: a strategy for improving worker productivity. International Journal of Occupational Safety and Ergonomics, 5: 417-430. 
GARDNER, D., CROSS, J.A., FONTAYNE, P.N., CARLOPIO, J. and SHIKDAR, A. 1997. Mechanical equipment injuries in small manufacturing businesses. Proceedings of the 13th Triennial Congress of the International Ergonomics Association , 109-111, Tempere, Finland.

GRANDJEAN, E. 1982. Fitting the task to the man: An ergonomic approach. Taylor and Francis, London, UK.

HASSELQUIST, R.J. 1981. Increasing manufacturing productivity using Human Factors principles. Proceedings of the Human Factors Society - $25^{\text {th }}$ Annual Meeting, 204-206.

KONZ, S. 1983. Work design: Industrial Ergonomics. (2nd edition), Grid Columbus, Ohio, USA.

MELAMED, S., LUZ, J., NAJEMSON, T., JUCHA, E., and GREEN, M. 1989. Ergonomic stress levels, personal characteristics, accident occurrence and sickness absence among factory workers. Ergonomics, 9: 1101-1110.

SANDERS, M.S. and McCORMIC, E.J. 1992. Human Factors in Engineering and Design. (6th edition), McGraw Hill, New York, USA.

SCHNAUBER, H. 1986. Ergonomics and productivity as reflected in a new factory. Trends in Ergonomics/Human Factors III, Karwowski Ed., Elsevier Science Publishers, 459-465.

SHIKDAR, A., CARLOPIO, J., CROSS, J., STANLEY, P. and GARDNER, D. 1993. Mechanical equipment injuries in small businesses. In Ergonomics in a Changing World, Proceedings of the Ergonomics Society of Australia, 199 - 205, Perth, Australia.

SHIKDAR, A.A. and DAS, B. 1995. A field study of worker productivity improvements. Applied Ergonomics, 26: 21-27.

RESNIK, M.L. and ZANOTTI, A. 1997. Using ergonomics to target productivity improvements. Computers and Industrial Engineering, 33: 185-188.

RAYAN, J.P. 1987. A study of safety in man-machine systems. In Asfour (Ed.), Trends in Ergonomics/Human Factors, IV, 505-511.

RAYAN, J.P. 1989. A study of selected ergonomic factors in occupational safety. Advances in Industrial Ergonomics and Safety I, Anil Mital (Ed), Taylor and Francis, 359-364.

ZAIDEL, D. 1989. Ergonomics and safety in small manufacturing shops (SMS). Advances in Industrial Ergonomics and Safety I, Anil Mital (Ed), Taylor and Francis, 391-397.

Received 24 January 2001

Accepted 24 June 2001 